\title{
The Industry-Academia Gap in Responsible Tourism Management: An Automated Content Analysis
}

\author{
Li-Hsin Chen ${ }^{\mathrm{a}}$; Chia-Shiang Hsu ${ }^{\mathrm{b} *}$; Kyrie Eleison Muñoz ${ }^{\mathrm{a}}$; Nandar Aye ${ }^{\mathrm{a}}$ \\ aThe International Master's Program in Tourism and Hospitality, National Kaohsiung University of Hospitality \\ and Tourism, Taiwan; ${ }^{b}$ Department of Hotel Management, National Kaohsiung University of Hospitality and \\ Tourism, Taiwan \\ *Correspondence: jacqueshsu@staff.nkuht.edu.tw; jacques.hsu@ hotmail.com
}

Received 4 February 2021; Revised 17 July 2021; Accepted 23 July 2021

\begin{abstract}
Studies are increasingly pointing to responsible tourism (RT) as an alternative approach to overcome the negative effects of mass tourism while supporting the economic, social, and environmental considerations of the destination stakeholders. However, there is ambiguity and confusion among academics and practitioners over the actual meaning and implementation of RT and its terminology. Furthermore, although news reports are the primary reference for the general public, past studies have not yet explored how RT is represented in the mass media. This study conducts a comparative analysis of the development of the concept of RT and travel using data from scholarly journal articles and news reports from 1993 to the present. A comparative automated content analysis (ACA) was used to generate, compare, and contrast the themes and concepts in academic journals and news reports to provide a deeper understanding of RT. The findings reveal that both academic articles and news reports focus on the approaches and practices of actors and stakeholders on both the supply and demand sides, but present some differences due to their respective intended audiences. This study identifies areas for future research and news reporting.
\end{abstract}

KEYWORDS: responsible tourism; responsible travel; automated content analysis; Leximancer; comparative analysis

\section{Introduction}

The potential contribution of tourism to economic growth and social benefits worldwide has been recognized in the literature. Prior to COVID-19, various stakeholders (e.g., hotels, tour operators, restaurants, destination management organizations [DMOs], and local communities) in the tourism industry prioritize profit maximization. However, the rapid increase in inbound and outbound travel has generated negative impacts globally. For the past 30 years, this situation has alarmed different tourism stakeholders and actors, prompting growing concerns about overcoming these effects by implementing sustainable practices (Sica, Sisto, Bianchi, \& Cappelletti, 2021). Responsible tourism (RT) is deemed to be a viable alternative (Wheeller, 1991) to maintain the economic and social benefits while preserving the environmental conditions of tourist destinations(Burrai, Buda, \& Stanford, 2019). 
The emergence of RT as a domain of its own has gained attention and critiques from tourism researchers (Burrai et al., 2019; Leslie, 2012; Mathew \& Sreejesh, 2017). However, the various claims made about the terminology, ideology, and characteristics of RT have led to confusion in the current discourse among academics and stakeholders alike (Cheng, 2016). This has pushed scholars to reconceptualize RT (Burrai et al., 2019) and reduce the ambiguity of the term so that stakeholders can more easily implement RT in the industry. For example, a systematic review of RT by Mondal and Samaddar (2021) identifies six key areas of RT research (e.g., environmentally responsible behavior, pro-environmental behavior, environmental knowledge and training, and corporate social responsibility). Despite this contribution, their study focuses only the literature on the Scopus database published from 2002, arguing that this covers the period since RT was first proclaimed. However, there are earlier references to RT. For example, Wheeler (1990) recognizes RT in their debate on creating an alternative form of tourism. Other papers arguing for and against RT prior to 2002 include Cooper and Ozdil (1992), Sirakaya and Sonmez (2000), Szczepanski (1992), and Wheeller (1991). Therefore, the study by Mondal and Samaddar (2021) is unlikely to resolve the confusion over the meaning of RT since the term was first coined and investigated in tourism studies.

Furthermore, to the best of our knowledge, no existing study has explored how the media (e.g., radio and television, news articles, magazines, the Internet) have portrayed and reported on RT. Understanding how RT is framed in news articles is important, as the news media play a distinct role in shaping and reinforcing public perceptions, especially in relation to social issues (Price, Tewksbury, \& Powers, 1997; Semetko \& Valkenburg, 2000). A comparison of scholarly articles and media content offers an opportunity to identify the themes and concepts that are crucial to the deeper meaning of the concept of RT. This study aims to fill this knowledge gap by systematically reviewing and comparing the related academic literature and news reports to offer insights for future research and practice. Specifically, this paper attempts to answer the following research questions:

\section{RQ1: What are the themes and concepts on RT published by in academic literature and new} reports?

RQ2: What are the similarities and differences between themes and concepts discussed by these two sources?

This study applies comparative automated content analysis (ACA) to address the challenge of analyzing a large quantity of data related to RT, producing over past decades. Using the ACA approach, this study observes current scholarly knowledge of RT and practice in the real world as described in the news media. Analyzing the relevant themes of RT in both the academic literature and news reports can help overcome the confusion and ambiguity in the RT discourse and identify the limitations of RT in practice. A comparative study between the current literature and news media discourse can offer insights into RT and help identify future research directions and practical implications. This may also help unify the efforts of governments, policymakers, DMOs, and other tourism stakeholders. 


\section{Literature Review}

\section{Responsible Tourism}

Awareness of the negative impacts of mass tourism and the rapid growth of travel has given rise to the reflection of tourism's role in the host communities. According to Wheeller (1990), tourism should be practiced with the tourists' responsibilities and respect to the natural, built, and cultural environments and the interests of all stakeholders in the host communities. This form of tourism seems a reasonable solution to the growing issue of mass tourism (Cohen, 1987; Nash \& Butler, 1990; Wheeller, 1994) and provokes the discussion of the responsibility of tourism in the literature (Valene L Smith, 1990). The term 'responsible tourism (RT)' was reportedly coined during the Cape Town Declaration on Responsible Tourism in 2002, which advocated for stakeholders in the tourism industry to take accountable and responsible actions to promote sustainability (Goodwin \& Font, 2014).

The existing body of knowledge commonly describes RT as all practices and approaches that highlight the importance of ethical and respectful behavior by tourism stakeholders, which can contribute to sustainability (Moscardo \& Murphy, 2014; Tay, Chan, Vogt, \& Mohamed, 2016). For example, in the Responsible Tourism Handbook of 2003, RT addresses the "triple bottom line," representing economic, social, and environmental responsibility (Mondal \& Samaddar, 2021). It can be relating to all forms of tourism, which are designed to promote business opportunities while taking into consideration the residents, environment, and natural resources of a given area (Spenceley et al., 2002). Furthermore, RT can be regarded as a form of sustainable activity that involves practices to alleviate the negative impacts of conventional tourism on destinations (Gong, Detchkhajornjaroensri, \& Knight, 2019). Therefore, the overall promise of RT revolves around creating meaningful destinations that both residents and tourists can share and benefit from (Goodwin, 2011). Namely, the ability of RT is to unite tourism stakeholders in realizing the United Nations Sustainable Development Goals (UN SDGs) to end poverty, protect the environment, and maximize benefits for all (Burrai et al., 2019; United-Nations, 2017).

However, the concept of RT is not without any criticism. For example, Wheeller (1990) criticizes RT as merely "a pleasant, agreeable, but dangerously superficial, ephemeral, and inadequate escape route for the educated middle classes unable, or unwilling, to appreciate or accept their/our own destructive contribution to the international tourism maelstrom" (p.96). Furthermore, Cooper and Ozdil (1992) argued that RT shows trivial consideration and understanding of what responsibility is. Scholars and practitioners simply want to build an alternative to mass tourism. Another issue is that the concept of RT is often associated with sustainable tourism due to the overlap of their respective definitions and purpose (Bramwell, Lane, McCabe, Mosedale, \& Scarles, 2008). RT has been widely discussed along with sustainability since the concept of sustainable tourism emerged (Bramwell et al., 2008). The early Brundtland Report (1987) defines sustainable development as "development that meets the needs of the present generation without compromising the ability of future generations to meet their own needs" (p.41). Both concepts are associated with the problems emerging from the rapid growth of travel in tourism. At first, RT was treated as an alternative sustainable development method in tourism (Godfrey, 1998). The conceptualization and ideology of RT and its contribution to sustainable development are widely discussed in many studies (see Mody, Day, Sydnor, Jaffe, and Lehto, 2014; Burrai et al., 2019; Merwe and Wocke, 2007). However, some scholars have the opposite perspectives and argue that sustainable tourism 
cannot be achieved through 'alternatives' to mainstream tourism (Budeanu, 2005). Additionally, RT is not merely a niche market of sustainable tourism (Casellas, 1997). In a nutshell, the lack of accurate definitions of RT and the unclear distinctions between sustainable tourism and RT have led to ambiguity and confusion among scholars and practitioners (Burrai et al., 2019).

Despite these criticisms, RT is seen as a feasible method to respond to the urgent call for more responsible production and consumption of tourism in light of 'overtourism' before COVID-19 (Mostafanezhad, Cheer, \& Sin, 2020). Scholars still believe that RT can point to a new era of tourism research with its recognition of environmental and ecological limits and a wider consciousness of social justice, equity, fairness, and responsibility (Jamal \& Higham, 2021). The research review by Mondal and Samaddar (2021) identifies six key research areas of RT: 1) environmentally responsible behavior, 2) pro-environmental behavior, 3) environmental knowledge and training, 4) corporate social responsibility agendas and RT, 5) green tourism and environmental responsibility, and 6) involvement and motivation in environmental management practices. This categorization complements the current discourse on RT, which strongly focus on environmental consciousness and promoting greater awareness among tourists and stakeholders. Although much has been written about tourists in the context of RT (e.g., environmental awareness and pro-environmental behavior among tourists), little work has been done on engaging tourists to become socially responsible for tourism development.

Besides, there is a greater focus on tourists than on policymakers (i.e., governments and DMOs). This may be the result of the current dilemma in RT over the implementation stage, that is, reaching agreement among stakeholders regarding the implications of RT practices.

When observing relevant academic journals focused on RT, we can conclude that although tourism-related studies attempt to conceptualize the characteristics of RT, the ambiguity of the concept has caused unsettled debates and arguments in our field. Furthermore, this confusion among researchers presents a challenge to the application of the concept in practice (R. Butler, 2015; Higgins-Desbiolles, 2010). Specifically, the lack of clarity over the meaning of this concept to the satisfaction of all stakeholders remains a fundamental issue for its implementation and practice, including monitoring and assessment (R. Butler, 1990). Evidently, more systematic reviews should be conducted in both academic studies and industrial documents to clearly guide RT research agendas and industrial development in the future.

\section{Industry-Academia Collaboration in Tourism Management: Challenges and Research Status}

Collaboration between industry and academia provides an opportunity to advance not only economic gains but also research and development (Chang \& Fu-Sheng, 2017). A strong working relationship between these two can yield mutually beneficial outcomes and new theoretical and managerial insights (Zaharia \& Kaburakis, 2016). Tourism education has played a major role in both theory and practice as industry practitioners can provide a glimpse of what actually happens beyond the classroom (Anderson \& Sanga, 2019). However, there is a disjunction in the integration of industry and academia (W. Griffin, 2020), as there are doubts about the receptiveness of academia to substantial input from the industry and about its responsiveness to the industry's needs (Assante, Huffman, \& Harp, 2008; Milman, 2001). 
This disconnect may be one cause of the ambiguous understanding of RT in the literature, as the ambiguous ideological characteristics of RT in the literature fail to raise awareness among stakeholders, who are the target audience of news articles (Burrai et al., 2019; Mondal \& Samaddar, 2021).

According to Zaharia and Kaburakis (2016), successful collaboration between industry and academia can be achieved by understanding the distinct role each plays in society. Indeed, such collaboration is a consistent theme in the literature (W. C. Griffin, 2019). However, communication is critical to meaningful collaboration (Berman, 2008), because the mass media play an intermediary role between academics and the general public, for whom news reports are a major point of reference, especially for currently unfolding phenomena (Zimmerman, Bisanz, Bisanz, Klein, \& Klein, 2001). Thus, the ambiguity and misunderstanding around RT among stakeholders can potentially be addressed by assessing the status of the relevant literature from industry and academia.

However, it may be challenging and tedious to manually examine the large quantity of data from academic literature and news articles generated over the past decades. Therefore, to effectively uncover the themes and concepts of RT developing from academic literature and news articles, this study applies ACA, which is a technique with performing statistical algorithms to detect hidden themes and conceptual patterns from a large quantity of text data (Cheng, 2016; Cheng, Edwards, Darcy, and Redfern, 2018; Jin and Wang, 2016). More details of ACA are explained in the following section.

\section{Methods}

\section{Data Collection}

The academic literature was selected using the preferred reporting items for systematic reviews and meta-analyses (PRISMA), illustrated in Figure 1, to guarantee the quality of the review process (Moher, Liberati, Tetzlaff, Altman, \& Group, 2009). To ensure comprehensiveness, the authors first extracted data from academic journals using two databases: (1) Web of Science (WOS) and (2) EBSCO Tourism and Hospitality Complete from January 1989 to November 2020, to cover the earliest possible entries in the databases. The keywords used for this search were "responsible tourism" and "responsible travel." The initial criteria identified 585 journal articles, from which 19 duplicate titles were removed. The articles were further screened to include only full-length peer-reviewed articles published in English, leaving 197 eligible articles. Finally, the authors manually analyzed the abstract and keywords to remove articles not focused on tourism and hospitality. Ninety-five articles, mostly from the field of environmental science and marine science, were thus eliminated. As a result, 102 titles were selected for analysis. 


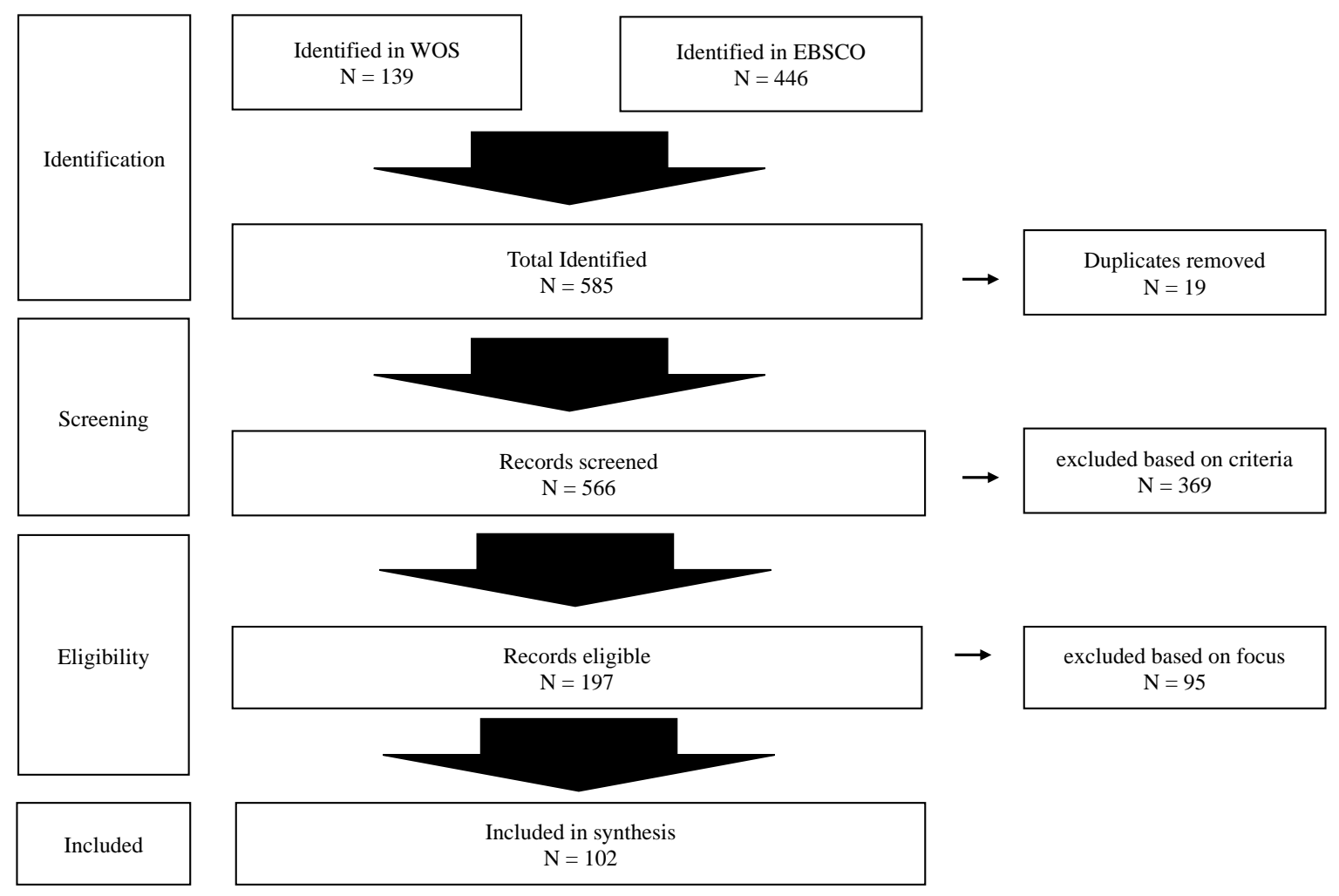

Figure 1: PRISMA Diagram

The news articles and reports were drawn from the ProQuest Newsstand database and the global news stream through the Google website (i.e., www.news.google.com), where categories of news articles can be selected using key terms. These two databases are believed to provide comprehensive, reliable, and complete English news articles from thousands of reputable sources (Cheng \& Edwards, 2019; Roblek, Thorpe, Bach, Jerman, \& Meško, 2020). The key terms used were "responsible tourism" and "responsible travel." The same search parameters and time frame used for the academic journals was applied to ensure comparability. Screening by the authors ensured that only news articles and reports discussing RT and responsibility were included. The initial search gathered 125 full-length news articles, from which three duplicate titles were discarded, leaving 122 news reports for analysis (see Appendix 2).

\section{Data Analysis}

ACA was chosen to analyze the data because it analyzes texts using an algorithm-based software program to extract concepts and themes(Blei, $\mathrm{Ng}$, \& Jordan, 2003). ACA was carried out using Leximancer V.5. This natural language processing software undertakes automated semantic analytics and provides a visual map containing the textual concept structure based on the data provided (Leximancer, 2018; A. E. Smith \& Humphreys, 2006). It is often applied to tourism studies (Boo \& Busser, 2018; Cheng et al., 2018; Rodrigues, Brochado, Troilo, \& Mohsin, 2017; J. Wang et al., 2021), because of its capacity to generate insights into the analytical relationships between texts and documents using an algorithm grounded in Bayesian theory(Boo \& Busser, 2018; Cheng \& Edwards, 2019; Sotiriadou, Brouwers, \& Le, 2014; Stepchenkova \& Morrison, 2006). The visual map shows concepts with strong semantic relationships and colored themes to denote their strength and significance(Angus, Rintel, \& Wiles, 2013; Campbell, Pitt, Parent, \& Berthon, 2011). 
Leximancer also calculates the connectivity rate of connected concepts within the themes (Leximancer, 2018). However, as human interpretation and understanding of the results are still required using macro- and micro-level insight into the data(McAbee, Landis, \& Burke, 2017), the authors familiarized themselves with the literature during the data collection process prior to using the ACA tool. ACA was performed in three stages. First, the journal articles selected were collated and transferred into a single document. The data were cleaned by removing irrelevant information such as author details, references, and acknowledgements that could influence the analysis phase(Cheng, Wong, Wearing, \& McDonald, 2017). Moreover, academic words that were common but irrelevant (e.g., "paper," "article") were deleted(Roblek et al., 2020; J. Wang, Liu-Lastres, Shi, \& Li, 2019). Second, a visual map of the concepts and themes was generated showing word frequency, co-occurrence, and the strength of the relationships between concepts and themes (J. Wang et al., 2019). Third, the comparison between the academic articles and news articles was facilitated by comparing and contrasting their themes and concepts to synthesize the findings.

\section{Findings}

\section{Responsible Tourism and Travel in the Academic Literature}

The final sample comprised 102 articles published in 43 journals from the WOS and EBSCO databases. Table 1 (see Appendix 1) shows the distribution of articles by journal. The results show that $47 \%$ of the titles came from three journals, namely the International Journal for Responsible Tourism, Sustainability, and Journal of Sustainable Tourism. These journals focus specifically on the principles of RT and travel. Intriguingly, among all journals, Sustainability is the only non-tourism journal, and it has published the second most papers on RT. This may indicate that scholars in other fields are also interested in investigating RT or maybe because tourism scholars are interested in publishing their works in other areas to raise more attention on RT. This result deserves more research in the future.

Table 1: List of Academic Journals where Articles were Published

\begin{tabular}{lcc}
\hline \multicolumn{1}{c}{ Journal Name } & Number of studies & Percentage \\
\hline International Journal for Responsible Tourism & 18 & $17.65 \%$ \\
Sustainability & 15 & $14.71 \%$ \\
Journal of Sustainable Tourism & 15 & $14.71 \%$ \\
Annals of Tourism Research & 4 & $3.92 \%$ \\
Tourism Geographies & 3 & $2.94 \%$ \\
Tourism Management Perspectives & 3 & $2.94 \%$ \\
Current Issues in Tourism & 2 & $1.96 \%$ \\
Tourism Management & 2 & $1.96 \%$ \\
International Journal of Hospitality \& Tourism Systems & 2 & $1.96 \%$ \\
Others & 38 & $37.25 \%$ \\
Total & 102 & $100 \%$ \\
\hline
\end{tabular}

Chart 1 shows the trend line of the selected articles from the two databases over the past 27 years. The earliest entry was published in 1993. Between 1993 and 2008, scholarly articles on RT and travel appeared on average once a year. The low number of publications may result from an overlap with the concepts of ecotourism, nature-based tourism, and sustainable tourism, which were gaining ground at that time. After 2009, there was a noticeable increase 
in the RT and travel literature, peaking in 2014. Although ecotourism remained popular during this time, there was a growing trend in community-based tourism(Sin \& Minca, 2014), volunteer tourism (McGehee, 2014; Sin, 2010; Victoria Louise Smith \& Font, 2014), and socially responsible tourism development (Gendzheva, 2014; Musavengane \& Steyn, 2013; von der Weppen \& Cochrane, 2012). This was followed by a decline from 2016 to 2018 when most research focused primarily on tourism impact assessments, framework development, and policy planning. However, research on RT and travel became flourish during 2019 and 2020.

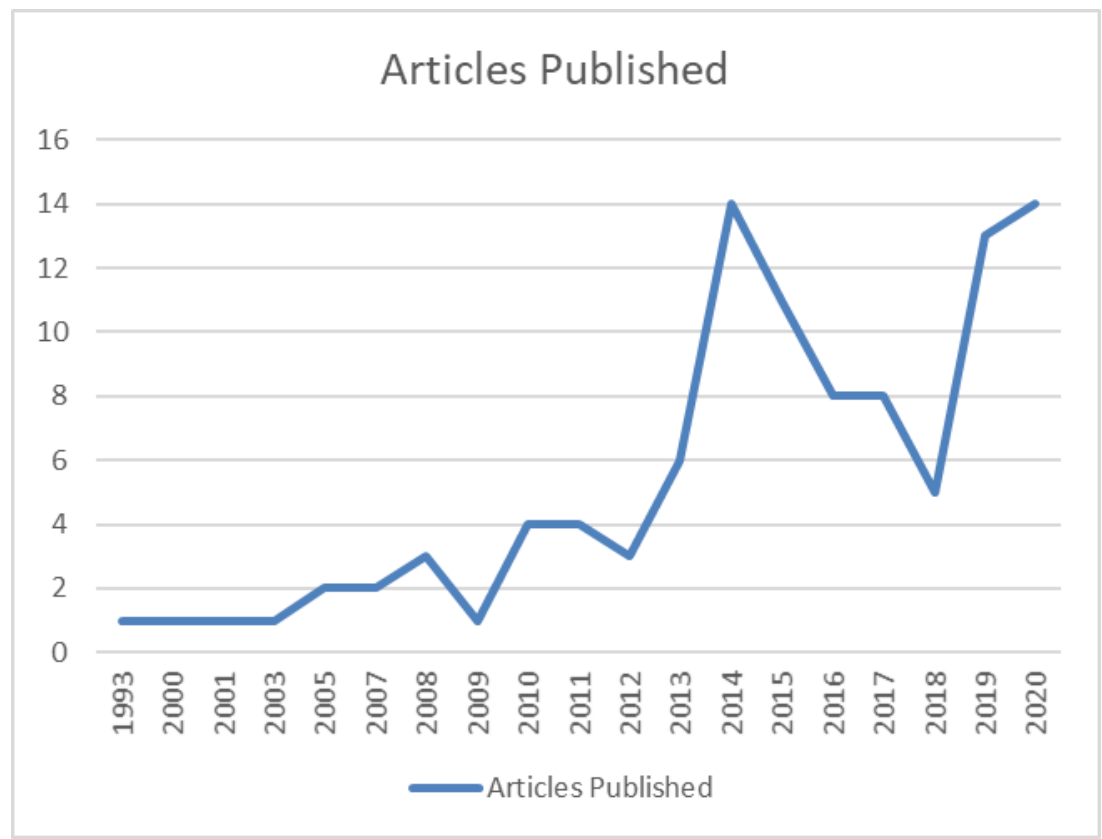

Chart 1: Trend Line on Articles Published in WOS and EBSCO

The visual map produced by Leximancer for the dataset of journal articles reveals 116 concepts and 5 themes. The large colored spheres indicating the themes are grouped and interconnected by small grey dots signifying the concepts (Wu, Wall, \& Pearce, 2014). The themes pertain to the clustering of concepts that are associated with each other based on common characteristics or connections, indicated by the closeness of the links in the map (Roblek et al., 2020). As illustrated in Figure 2, the themes include "Tourism" (7,176 hits), "Tourists" (1,533 hits), "Studies" (503 hits), "Countries" (451 hits), and "Hotels" (414 hits). Moreover, the conceptual map shows that these themes tend to overlap, especially when the concepts appear to fall under more than one theme. The five significant themes mentioned above are considered to be the primary foci in the academic literature. Additional significant concepts under the themes are also considered (see Table 2). 


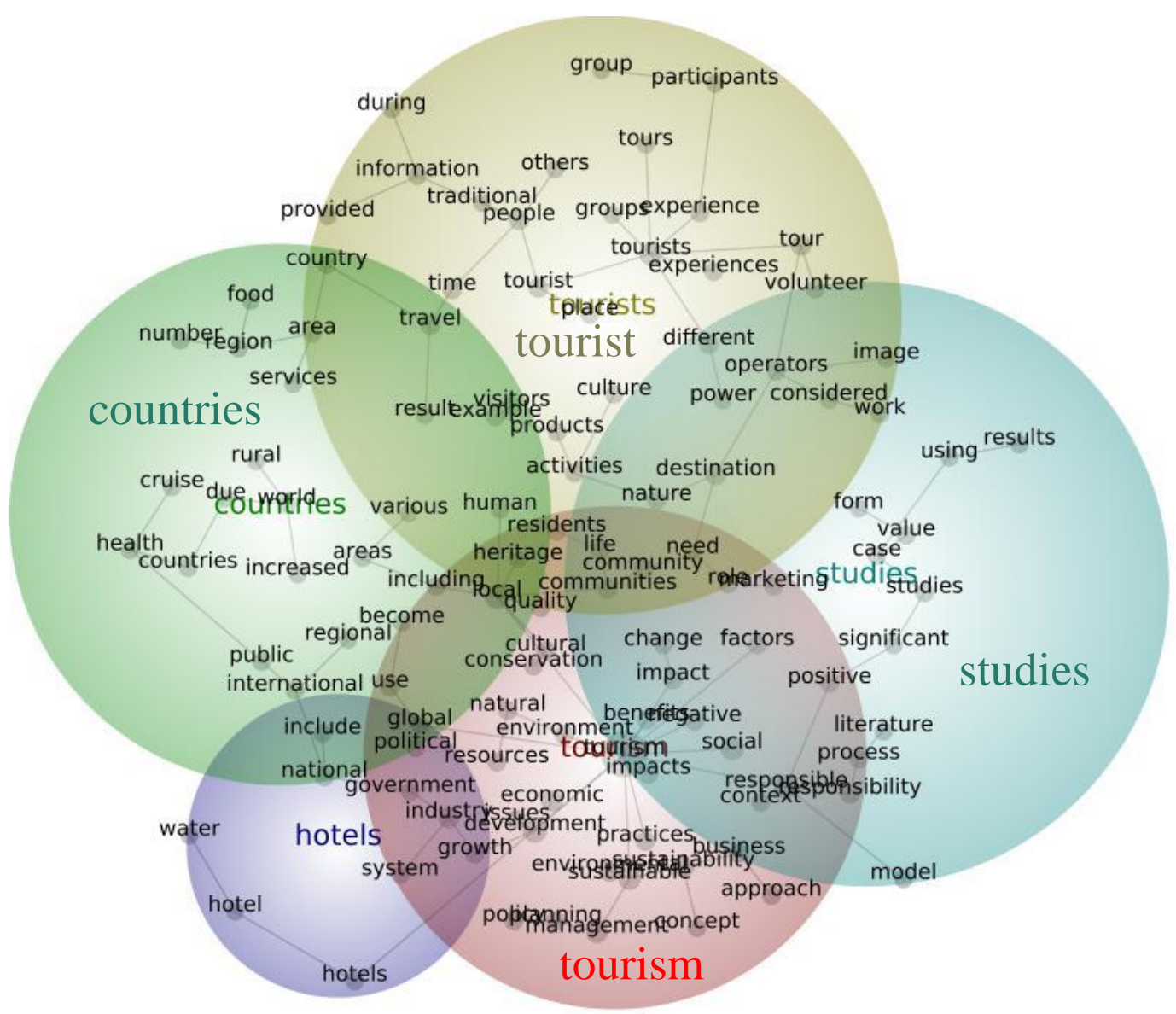

Figure 2: Concept Map of Responsible Tourism and Travel in Academic Literature

The theme "Tourism" occurs most often in the data and covers concepts such as "responsible" ( $\mathrm{n}=1,703,24 \%$ relevance $)$, "development" $(\mathrm{n}=1,480,21 \%$ relevance $)$, "sustainable" ( $\mathrm{n}=1,096,15 \%$ relevance), and "industry" ( $\mathrm{n}=795,11 \%$ relevance). Furthermore, most of the concepts of the "Tourism" theme in academia are interrelated with words connected to the contribution of RT (such as "economic," "social," "environmental," "development," and "growth") and the implications of RT (such as "government," "policy," and "practice"). The research stream in this area broadly covers the planning, development, and management approaches of various stakeholders in RT and travel. Governments and businesses are seen to be creating, enforcing, and engaging in policies and practices to support economic, environmental, social, and cultural sustainability. This is evidenced by approaches to improve the sustainable management of various tourism destinations (Conaghan, Hanrahan, \& McLoughlin, 2015), implement green strategies in hotels (Jelica, Dragica, Lukrecija, Ivana, \& Srdjan, 2015), and safeguard cultural preservation through balanced business models (Karolev \& Olson, 2017).

"Tourists" is also a key theme covering "people" ( $\mathrm{n}=780,11 \%$ relevance), "experience" $(\mathrm{n}=520,7 \%$ relevance), and "activities" ( $\mathrm{n}=471,7 \%$ relevance). This theme emerges from the literature discussing the individual actors involved in travel and tourism. It is linked with the concepts "destination," "impact," "quality," and "role." As the participants in tourism activities, tourists play an important role in responsible and sustainable travel. Studies classified under this theme mainly discuss consumers' motivations, perceptions, attitudes, values, involvement, understanding, satisfaction, and behavioral intention toward RT and travel (Chen, Jong, Hsu, \& Lin, 2021). This can be attributed to the effects of tourist behavior 
on environmental phenomena such as climate change (Paris, Hopkins, \& Westbrook, 2011). For instance, tourists' attitudes and values are observed to have a high preference for RT behavior (Parsons et al., 2003). The concept "impact" suggests assessment of the positive and negative effects on a destination. Studies widely discuss the impact of tourism and its assessment and monitoring to support RT development and facilitate a practical approach (e.g., McCombes, Vanclay, and Evers, 2015; Pope, Wessels, Douglas, Hughes, and MorrisonSaunders, 2019; Wang, Chang, Cui, Qi, and Li, 2020). The role of governments and DMOs is to minimize negative impacts and secure the involvement of stakeholders, including local communities, while contributing to the quality of life in the destination area (Musgrave \& Raj, 2009).

The themes "Countries" and "Hotels" complement the two abovementioned themes. They play an important role in the discourse as both affect the supply and demand sides of tourism. The reviewed studies point to hotels as prime venues for promoting and implementing RT strategies. Musavengane (2019) proposes an RT model suggesting that hotels engage with the public sector through education and economic and marketing stimulation, and create social connections to realize RT. Importantly, customers' travel decisions and experiences are shaped and influenced by intersecting trends in sustainability and related issues affecting society (see, for example, d'Angella and De Carlo, 2016; Dragulanescu and Dragulanescu, 2013; Saarinen, 2014; Dos Santos, Neves, Sant'Anna, de Oliveira, and Carvalho, 2019). Last, the theme "Studies" is related to the growth and development of RT and travel in the academic literature. The main concepts under this theme are "case" ( $n=439,6 \%$ relevance), "value" ( $n=438,6 \%$ relevance), and "literature" ( $n=401,6 \%$ relevance). This may reflect the growing appeal for current empirical studies on RT in practice (see, for example, Gökdeniz, Erdem, and Çeken, 2014; Jelica et al., 2015; Wafik, Fawzy, and Ibrahim, 2011).

Table 2: Significant Themes and Concepts in Relevance of RT Literature

\begin{tabular}{clcc}
\hline Theme & Concepts & No. of occurrences & Relevance (\%) \\
\hline \multirow{5}{*}{ Tourism } & Responsible & 1703 & 24 \\
& Development & 1480 & 21 \\
& Sustainable & 1096 & 15 \\
& Industry & 795 & 11 \\
& People & 780 & 11 \\
Tourists & Experience & 520 & 7 \\
& Activities & 471 & 7 \\
& Case & 439 & 6 \\
& Value & 438 & 6 \\
& Literature & 401 & 6 \\
\hline
\end{tabular}

*Other interrelated concepts with relatively low relevance are not described.

\section{Responsible Tourism and Travel in News Reports}

Figure 3 suggests five significant themes discussing RT and travel within news articles. These include "Tourism" (630 hits), "People" (253 hits), "Environment" (123 hits), "Hotels" (40 hits), and "Experience" (30 hits). Additional significant concepts under the themes are included. (See Table 3). 


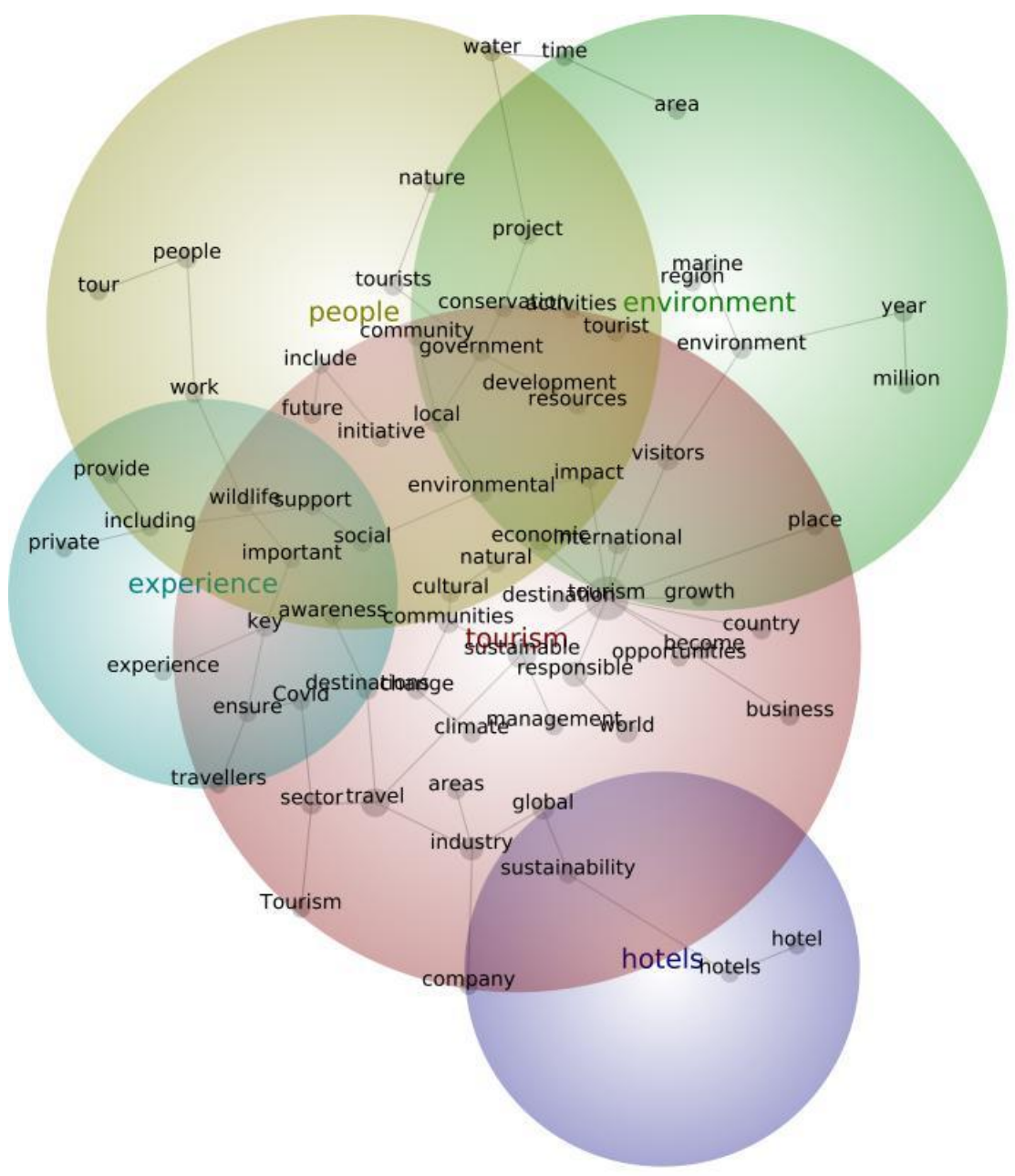

Figure 3: Concept Map of Responsible Tourism and Travel in News Reports

In the news media, "Tourism" is the dominant theme, associated with the concepts "travel" (n $=146,48 \%$ relevance), "sustainable" ( $n=131,43 \%$ relevance), and "industry" ( $n=85,28 \%$ relevance). This suggests that RT and travel are associated with sustainable practices initiated mainly by the different operating sectors in the industry in the form of private sector awards ceremonies for sustainable tourism(Skal-International, 2020), government support for sustainability (BTMI/MT/BGIS, 2016; Market, 2016), adherence to the UN SDGs (A. Butler, 2017), and public-private collaboration on sustainable efforts (Wan, 2019). Leximancer further shows "covid" as an important concept despite its low relevance rate. This indicates increased concern over the importance of RT in COVID-19-conscious travel resilience, recovery, and the rebuilding of tourism (UNESCO, 2020). As a change in strategy in light of COVID-19, the UNESCO debate on tourism recovery stresses the importance of responsible travel choices. This involves the idea of regarding tourists as respectful and responsible visitors during COVID-19 conscious travel (Kohler, 2020).

The theme "People" consists of the concepts "local" ( $\mathrm{n}=82,27 \%$ relevance), "tourist" $(\mathrm{n}=35$, $11 \%$ relevance), and "community" ( $\mathrm{n}=32,10 \%$ relevance). The results reveal that these actors not only engage in RT and travel but are also affected by, and contribute to, irresponsible tourism activities. For example, Seoul has been keen in promoting responsible behavior for locals (Germier-Hamel, 2018), while Iceland has used educational tools to reinforce positive behavior by visitors (Sziakov, 2018). Moreover, this shows how the media portray the importance of tourists, locals, and the community as stakeholders in the tourism process. 
Further concepts associated with both "Tourism" and "People" in news articles are "economic," "social," "cultural," and "environmental" related to the triple bottom line to maximize economic benefits while minimizing the negative social, cultural, and environmental impacts for the people (Frey \& George, 2010).

Under the theme "Environment," the main concepts are "visitors" ( $\mathrm{n}=60,20 \%$ relevance), "international" ( $\mathrm{n}=42,14 \%$ relevance), and "development" ( $\mathrm{n}=40,14 \%$ relevance). This indicates the constant presence of the accommodation sector in news articles as hotel companies engage in green initiatives, such as minimizing their carbon emissions and carbon footprint, which complement the thrust of sustainability (Weston \& Bondy, 2010). Because RT and travel are mainly concerned with the environment, this theme highlights the essential contribution of international visitors to the development of destinations. News reports attempt to support responsible tourist behavior for the benefit of the environment. Furthermore, the concept "impact," linking the theme "Environment" with the previous themes (i.e., "Tourism" and "People") indicates mutual concern about environmental impact among stakeholders in recent studies (see Pope et al., 2019; Wang, Yuen, Wong, and Li, 2020).

Similarly, the theme "Hotel" focuses on the concept's "hotels" ( $\mathrm{n}=40,13 \%$ relevance) and "company" ( $\mathrm{n}=36,12 \%$ relevance). This indicates the constant presence of the accommodation sector in news articles as hotel companies engage in green initiatives, such as minimizing their carbon emissions and carbon footprint, which complement the thrust of sustainability (Cheer, 2020). Furthermore, the results suggest that hotels are secondary to the environment when it comes to the destination where RT practices are observed. Apart from hotels, other destination operators such as restaurants, travel agencies, and transportation are hardly discussed.

Finally, the theme "Experience" is associated with the concept's "experience" $(n=30,10 \%$ relevance) and "private" ( $\mathrm{n}=22,7 \%$ relevance). Contrary to the conventional desire for quality and authenticity in travel experiences, the emphasis on experience in news articles is on the steadfast efforts of the private sector to create tour packages and activities focused on responsible behavior, prioritizing sustainability and pro-environmental activities(Fox, 2019).

Table 3: Significant Themes and Concepts in Relevance of RT News Articles

\begin{tabular}{|c|c|c|c|}
\hline Theme & Concepts & No. of occurring & Relevance (\%) \\
\hline \multirow{3}{*}{ Tourism } & Travel & 146 & 48 \\
\hline & Sustainable & 131 & 43 \\
\hline & Industry & 85 & 28 \\
\hline \multirow{3}{*}{ People } & Local & 82 & 27 \\
\hline & Tourist & 35 & 11 \\
\hline & Community & 32 & 10 \\
\hline \multirow{3}{*}{ Environment } & Visitors & 60 & 20 \\
\hline & International & 42 & 14 \\
\hline & Development & 40 & 14 \\
\hline \multirow{2}{*}{ Hotel } & Hotels & 40 & 13 \\
\hline & Company & 36 & 12 \\
\hline \multirow{2}{*}{ Experience } & Experience & 30 & 10 \\
\hline & Private & 22 & 7 \\
\hline
\end{tabular}

*Other interrelated concepts with relatively low relevance are not described. 


\section{Discussions}

\section{Comparison of Themes in Academic Journals and News Reports}

The analysis of the data from both sources indicates some common topics related to RT and travel. First, both academic journals and news articles discuss tourism as a discipline and an activity (A. Butler, 2017; Conaghan et al., 2015). Interestingly, both sources link this theme to the discourse on sustainable approaches and practices by various institutions (e.g., governments, businesses, organizations) on the supply side. Second, both also relate this theme to the demand side, such as locals, tourists, and people (Font et al., 2021; Parsons et al., 2003). Third, both sources link RT to sustainable development and the underlying concept of the triple bottom line, which complies with RT by contributing to the conservation of natural and cultural heritage while minimizing negative impacts (Frey \& George, 2010). Fourth, the literature points specifically to hotels as a sector that influences both businesses and consumers. Hotels appear to be the common ground where RT practices are seen as critical. These can include internal initiatives by individual hotels or approaches by the hotel sector that contribute to sustainable behavior. Moreover, other equally important sectors of tourism (e.g., restaurants, travel agencies, and transportation) are rarely discussed, and technological intervention in RT is not significantly highlighted in either source. This paper suggests that although these two sources publish their articles separately and independently, they show a general consensus on the trends and issues in RT and travel, despite the ambiguity and confusion in the academic RT discourse.

However, there are also striking differences in the themes emerging from the two sources. First, "countries" is a common theme in journal articles and tends to encompass macro-level destinations, whereas news reports tend to discuss RT issues and practices in specific geographical areas. Second, although most journal articles attempt to contribute to both theory and practice, our results reveal that the RT literature focuses more on scholarly discourse, whereas news reports have maintained their content possibly to suit their target readership. Although both sources agree on stakeholder involvement, only academic journals widely discuss the implications of RT for policy and practice. This suggests that although researchers realize the important implications of RT, the policy guidelines developed in academic journals have not yet drawn the attention and resulting intervention of policymakers. Most importantly, COVID-19, an emerging RT issue in news reports, remains rarely discussed in the literature. This phenomenon can attribute to the rapidity of publication of news report articles compared to academic journals. Therefore, to increase the timely impacts of academic research, researchers should try to engage with the public media to raise awareness about their findings to the public and policymakers. Finally, "studies" appears as a common theme in academic journals but is rarely mentioned in news reports, whereas "experiences" is a theme in tourism-related news reports but receives little mention in the literature. These differences reveal distinctions in the character, purpose, and intended audience of each source. However, awareness of these differences provides opportunities for both researchers and media practitioners for future inquiries into RT.

These findings from the academic literature and news articles on RT reveal themes and key concepts and also identify new and emerging research areas and agendas. The analysis of both sources identifies important areas in the RT literature, such as RT planning and development, tourist behavior, stakeholder collaboration, and the roles of decision makers, and broader areas in news reports, i.e. stakeholder collaboration and environmental impacts. These 
important areas align with the key research areas identified by Mondal and Samaddar (2021), especially in terms of RT behavior and associated research agendas, i.e., the involvement of stakeholders and their role in the implementation of RT.

The comparison between the two data sources suggests that the RT literature has not yet fully addressed the issues emerging in news articles: (1) the need for policies and guidelines for decision makers; (2) RT recovery plans and initiatives for the COVID-19 era; and (3) RT experiences. Although many studies in the literature provide RT policies and guidelines that create opportunities for governments and stakeholders, future studies should address their awareness of such proposals. Governments play a positive role in implementing RT practices through collaboration with different stakeholders including DMOs (Font et al., 2021). To apply RT policies effectively, decision makers need binding frameworks for practice starting at the level of local implementation (Mondal \& Samaddar, 2021). Future researchers should consider this gap so that RT can produce better outcomes for tourism stakeholders, which can inspire them to take responsibility themselves(Bibi et al., 2021). Furthermore, news articles raise the issue of COVID-19, demonstrating the role of RT in the recovery and rebuilding of tourism. Increasingly, researchers are required to demonstrate responsible recovery tourism to address the current issues in news articles. Finally, the results show that the involvement and contribution of technology are rarely discussed in both sources, suggesting the need to include RT and technology in the future research agenda.

\section{Conclusion}

This study reviews the discourse in the academic literature and news media related to RT and travel, criticized for its ambiguous and confusing conceptual and ideological characteristics. ACA was applied to the large volume of qualitative data collected systematically to efficiently detect themes and concept patterns (Cheng, 2016; Cheng et al., 2017; Jin \& Wang, 2016; MacKinnon, 2015; Newman, Noh, Talley, Karimi, \& Baldwin, 2010; J. Wang et al., 2019). The use of Leximancer made it easier to systematically compare and analyze the different types of qualitative data (e.g., Cheng and Edwards, 2019; Cheng, 2016).

Furthermore, the study compares the themes and concepts found in the academic literature with those found in news articles. Both sources emphasize responsible and sustainable approaches and practices in terms of individual actors and stakeholders on both the supply side (A. Butler, 2017; Conaghan et al., 2015) and the demand side (Germier-Hamel, 2018). Both sources also discuss the importance of ensuring sustainability in the triple bottom line through RT practices and contributions. However, there are also differences between the two sources as each focus on its own target readers. The results highlight two important gaps between the themes and concepts of the two sources. First, the urgency and importance of RT related to the COVID-19 pandemic is far stronger among the news articles aimed at the general public than the RT literature. In addition, although the RT literature emphasizes RT policies and guidelines, a lack of awareness of these suggested guidelines is revealed among policymakers, governments, and stakeholders.

This study makes four contributions to the literature. First, it offers a visual map of the themes and concepts present in the current discourse on RT in both journal articles and news reports. Second, it compares the themes in the two sources to give meaning to the current body of knowledge on the topic. Third, it furthers the methodology of comparative ACA in the context of travel and tourism, which can be applied in future research. Finally, it offers 
new avenues for future research and news reporting. In addition, the results tend to support the findings of other studies (Burrai et al., 2019; Mondal \& Samaddar, 2021), concerning stakeholder awareness and the implementation of the guidelines proposed in the literature.

\section{Limitations and Future Research Suggestions}

Despite the contributions of this study, the authors acknowledge certain limitations. First, the literature sample was drawn from only two databases and subjected to further exclusion criteria. Thus, it did not contain all academic research on this topic. Future research could include more databases and expand the criteria (e.g., other languages, conference papers). Second, this study did not consider word-like and name-like frequencies when comparing academic articles with newspaper reports. Third, the concepts specific to each source were not mapped in this paper. More importantly, although this study focused on a comparative analysis of themes and concepts between academic journals and new articles, it did not explore the evolution of these themes over time or develop a conceptual framework. Future research could address these aspects to further compare the available literature.

\section{References}

Anderson, W., \& Sanga, J. J. (2019). Academia-industry partnerships for hospitality and tourism education in Tanzania. Journal of Hospitality \& Tourism Education, 31(1), 34-48.

Angus, D., Rintel, S., \& Wiles, J. (2013). Making sense of big text: a visual-first approach for analysing text data using Leximancer and Discursis. International Journal of Social Research Methodology, 16(3), 261-267.

Assante, L. M., Huffman, L., \& Harp, S. S. (2008). Conceptualization of quality indicators for US based four-year undergraduate hospitality management programs. Journal of Teaching in Travel \& Tourism, 7(2), 51-71.

Berman, J. (2008). Connecting with industry: bridging the divide. Journal of Higher Education Policy and Management, 30(2), 165-174.

Bibi, S., Khan, A., Hayat, H., Panniello, U., Alam, M., \& Farid, T. (2021). Do hotel employees really care for corporate social responsibility (CSR): a happiness approach to employee innovativeness. Current Issues in Tourism, 1-18. doi:10.1080/13683500.2021.1889482.

Blei, D. M., Ng, A. Y., \& Jordan, M. I. (2003). Latent dirichlet allocation. Journal of Machine Learning Research, 3, 993-1022.

Boo, S., \& Busser, J. A. (2018). Meeting planners' online reviews of destination hotels: A twofold content analysis approach. Tourism Management, 66, 287-301.

Bramwell, B., Lane, B., McCabe, S., Mosedale, J., \& Scarles, C. (2008). Research perspectives on responsible tourism. Journal of Sustainable Tourism, 16(3), 253-257. doi:10.1080/09669580802208201

Brundtland, G. H. (1987). Our common future-Call for action. Environmental Conservation, 14(4), 291-294. 
BTMI/MT/BGIS. (2016). Barbados enters phase two of sustainable tourism initiative. NationNews. Retrieved from https://www.nationnews.com/2016/03/31/barbadosenters-phase-two-of-sustainable-tourism-initiative/.

Budeanu, A. (2005). Impacts and responsibilities for sustainable tourism: a tour operator's perspective. Journal of Cleaner Production, 13(2), 89-97.

Burrai, E., Buda, D.-M., \& Stanford, D. (2019). Rethinking the ideology of responsible tourism. Journal of Sustainable Tourism, 27(7), 992-1007.

Butler, A. (2017. December 6). Hello Kitty is now a UN ambassador for sustainable tourism. Lonely Planet. Retrieved from https://www.lonelyplanet.com/articles/hello-kitty-unambassador-tourism.

Butler, R. (1990). Alternative tourism: pious hope or Trojan horse? Journal of Travel Research, 28(3), 40-45.

Butler, R. (2015). The evolution of tourism and tourism research. Tourism Recreation Research, 40(1), 16-27.

Campbell, C., Pitt, L. F., Parent, M., \& Berthon, P. R. (2011). Understanding consumer conversations around ads in a Web 2.0 world. Journal of Advertising, 40(1), 87-102.

Casellas, A. (1997). Practicing Responsible Tourism: International Case Studies in Tourism Planning, Policy and Development. Journal of the American Planning Association, 63(4), 536-537.

Chang, Y.-F., \& Fu-Sheng, T. (2017). The importance of knowledge assets on universityindustry collaboration: A preliminary analysis. Journal of Economics Bibliography, 4(2), 174-181.

Cheer, J. M. (2020). Human flourishing, tourism transformation and COVID-19: a conceptual touchstone. Tourism Geographies, 22(3), 514-524. doi:10.1080/14616688.2020.1765016.

Chen, S.-C., Jong, D., Hsu, C.-S., \& Lin, C.-H. (2021). Understanding Extended Theory of Planned Behavior to Access Backpackers' Intention in Self-Service Travel Websites. Journal of Hospitality Tourism Research. doi:10.1177/1096348021994166.

Cheng, M. (2016). Sharing economy: A review and agenda for future research. International Journal of Hospitality Management, 57, 60-70.

Cheng, M., \& Edwards, D. (2019). A comparative automated content analysis approach on the review of the sharing economy discourse in tourism and hospitality. Current Issues in Tourism, 22(1), 35-49.

Cheng, M., Edwards, D., Darcy, S., \& Redfern, K. (2018). A tri-method approach to a review of adventure tourism literature: Bibliometric analysis, content analysis, and a quantitative systematic literature review. Journal of Hospitality \& Tourism Research, 42(6), 997-1020.

Cheng, M., Wong, I. A., Wearing, S., \& McDonald, M. (2017). Ecotourism social media initiatives in China. Journal of Sustainable Tourism, 25(3), 416-432.

Cohen, E. (1987). "Alternative Tourism"-A Critique. Tourism Recreation Research, 12(2), 13-18. 
Conaghan, A., Hanrahan, J., \& McLoughlin, E. (2015). A model for the transition towards the sustainable management of tourism destinations in Ireland. International Journal for Responsible Tourism, 4(2), 103-122.

Cooper, C., \& Ozdil, I. (1992). From mass to 'responsible'tourism: the Turkish experience. Tourism Management, 13(4), 377-386.

d'Angella, F., \& De Carlo, M. (2016). Orientation to sustainability and strategic positioning of destinations: an analysis of international tourism websites. Current Issues in Tourism, 19(7), 624-633.

Dos Santos, P. H., Neves, S. M., Sant'Anna, D. O., de Oliveira, C. H., \& Carvalho, H. D. (2019). The analytic hierarchy process supporting decision making for sustainable development: An overview of applications. Journal of Cleaner Production, 212, 119138.

Dragulanescu, I.-V., \& Dragulanescu, N. (2013). Some theories of environmental sustainability. Romanian Statistical Review, 12, 14-22.

Font, X., Torres-Delgado, A., Crabolu, G., Palomo Martinez, J., Kantenbacher, J., \& Miller, G. (2021). The impact of sustainable tourism indicators on destination competitiveness: the European Tourism Indicator System. Journal of Sustainable Tourism. doi: 10.1080/09669582.2021.1910281.

Fox, J. T. (2019). HM on location: Responsible travel topic of Skift Global Forum. Retrieved from https://www.hotelmanagement.net/own/hm-location-responsible-travel-topicskift-global-forum.

Frey, N., \& George, R. (2010). Responsible tourism management: The missing link between business owners' attitudes and behaviour in the Cape Town tourism industry. Tourism Management, 31(5), 621-628. doi: 10.1016/j.tourman.2009.06.017.

Gökdeniz, A., Erdem, B., \& Çeken, H. (2014). Eco-friendly practices in the lodging industry: the case of Ayvalik Cunda Ortunc Hotel, Turkey. International Journal for Responsible Tourism, 3(1), 7.

Gendzheva, N. (2014). Model of corporate social responsibility in food tourism. International Journal for Responsible Tourism, 3(1), 44.

Germier-Hamel, C. (2018). Seoul spearheads global efforts to promote sustainable urban tourism. Retrieved from https://sustainablebrands.com/read/behavior-change/seoulspearheads-global-efforts-to-promote-sustainable-urban-tourism.

Godfrey, K. B. (1998). Attitudes towards 'sustainable tourism'in the UK: a view from local government. Tourism Management, 19(3), 213-224.

Gong, J., Detchkhajornjaroensri, P., \& Knight, D. W. (2019). Responsible tourism in Bangkok, Thailand: Resident perceptions of Chinese tourist behaviour. International Journal of Tourism Research, 21(2), 221-233.

Goodwin, H., \& Font, X. (2014). Progress in responsible tourism. Oxford, UK: Goodfellow.

Goodwin, S. (2011). Analysing policy as discourse: Methodological advances in policy analysis, in L. Markauskaite, P. Freebody \& J. Irwin (Ed.), Methodological choice and design: Scholarship, policy and practice in social and educational research (pp. 167186). Dordrecht, Netherlands: Springer. 
Griffin, W. (2020). Hospitality faculty: Are we meeting the demands of industry? Journal of Teaching in Travel \& Tourism, 20(4), 262-283.

Griffin, W. C. (2019). Hospitality industry's perceptions of industry-academia collaboration in curriculum development (Doctoral dissertation, Concordia University, St. Paul). Retrieved from https://digitalcommons.csp.edu/cup_commons_grad_edd/288.

Higgins-Desbiolles, F. (2010). The elusiveness of sustainability in tourism: The cultureideology of consumerism and its implications. Tourism and Hospitality Research, 10(2), 116-129.

Jamal, T., \& Higham, J. (2021). Justice and ethics: towards a new platform for tourism and sustainability. Journal of Sustainable Tourism, 29(2-3), 143-157. doi:10.1080/09669582.2020.1835933.

Jelica, M., Dragica, T., Lukrecija, D., Ivana, M., \& Srdjan, M. (2015). Impacts of green marketing strategies on benefits of hotels: The case from Serbia. International Journal for Responsible Tourism, 4(2), 7-22.

Jin, X., \& Wang, Y. (2016). Chinese outbound tourism research: A review. Journal of Travel Research, 55(4), 440-453. doi:10.1177/0047287515608504.

Karolev, V., \& Olson, R. O. (2017). The myth, reality and future of tourists' and travel industry responsibilities: a model for sustainable tourism in protected areas and its applications in Bulgaria. Revista Turismo \& Desenvolvimento, 2(27/28), 161-163.

Kohler, J. (2020, June 13). As some Colorado hotspots start seeing an uptick in visits, tourism office launches COVID-conscious campaign. The Denver Post. Retrieved from https://www.denverpost.com/2020/06/13/tourism-office-launches-care-forcoloradans/.

Leslie, E. (2012). Responsible tourism: Concepts, theory and practice. Wallingford, UK: CABI.

Leximancer. (2018). Leximancer user guide. Retrieved from https://doc.leximancer.com/doc/LeximancerManual.pdf.

MacKinnon, M. (2015). Representations of homelessness in 'The Australian' newspaper, 2008-2012. The Australian Journalism Review, 37, 165-176.

Market, C. (2016). MoU Signed Between M/O Tourism and Ecotourism Society of India for Responsible and Sustainable Tourism. Business Standard. Retrieved from https://www.business-standard.com/article/news-cm/mou-signed-between-m-otourism-and-ecotourism-society-of-india-for-responsible-and-sustainable-tourism116031500549_1.html.

Mathew, P. V., \& Sreejesh, S. (2017). Impact of responsible tourism on destination sustainability and quality of life of community in tourism destinations. Journal of Hospitality and Tourism Management, 31, 83-89.

McAbee, S. T., Landis, R. S., \& Burke, M. I. (2017). Inductive reasoning: The promise of big data. Human Resource Management Review, 27(2), 277-290.

McCombes, L., Vanclay, F., \& Evers, Y. (2015). Putting social impact assessment to the test as a method for implementing responsible tourism practice. Environmental Impact Assessment Review, 55, 156-168. 
McGehee, N. G. (2014). Volunteer tourism: Evolution, issues and futures. Journal of Sustainable Tourism, 22(6), 847-854.

Merwe, M., \& Wocke, A. (2007). An investigation into responsible tourism practices in the South African hotel industry. South African Journal of Business Management, 38(2), $1-15$.

Milman, A. (2001). Hospitality and tourism curriculum development: A qualitative casestudy approach. Journal of Teaching in Travel \& Tourism, 1(4), 65-76.

Mody, M., Day, J., Sydnor, S., Jaffe, W., \& Lehto, X. (2014). The different shades of responsibility: Examining domestic and international travelers' motivations for responsible tourism in India. Tourism Management Perspectives, 12, 113-124. doi:10.1016/j.tmp.2014.09.008.

Moher, D., Liberati, A., Tetzlaff, J., Altman, D. G., \& Group, P. (2009). Reprint—preferred reporting items for systematic reviews and meta-analyses: the PRISMA statement. Physical Therapy, 89(9), 873-880.

Mondal, S., \& Samaddar, K. (2021). Responsible tourism towards sustainable development: literature review and research agenda. Asia Pacific Business Review, 27(2), 229-266. doi:10.1080/13602381.2021.1857963.

Moscardo, G., \& Murphy, L. (2014). There is no such thing as sustainable tourism: Reconceptualizing tourism as a tool for sustainability. Sustainability, 6(5), 2538-2561.

Mostafanezhad, M., Cheer, J. M., \& Sin, H. L. (2020). Geopolitical anxieties of tourism:(Im) mobilities of the COVID-19 pandemic. Dialogues in Human Geography, 10(2), 182186.

Musavengane, R. (2019). Small hotels and responsible tourism practice: Hoteliers' perspectives. Journal of Cleaner Production, 220, 786-799.

Musavengane, R. \& Steyn, J.N. (2013). Responsible Tourism Practices in the Cape Town hotel sub-sector. International Journal of Hospitality \& Tourism Systems, 6(2), 52-63.

Musgrave, J. and Raj, R. (2009). Introduction to a conceptual framework for sustainable events. In Raj, R. and Musgrave, J. (Ed.), Event management and sustainability (pp. 1-12). Wallingford, UK: Cabi Series.

Nash, D., \& Butler, R. (1990). Towards sustainable tourism. Tourism Management, 11(3), 263-264.

Newman, D., Noh, Y., Talley, E., Karimi, S., \& Baldwin, T. (2010). Evaluating topic models for digital libraries. Paper presented at the proceedings of the 10th annual joint conference on digital libraries, Gold Coast.

Paris, C., Hopkins, S., \& Westbrook, T. (2011). Tourists perceptions of climate change in Cairns, Australia. e-Review of Tourism Research, 9(6), 279-291.

Parsons, E., Warburton, C., Woods-Ballard, A., Hughes, A., Johnston, P., Bates, H., \& Lück, M. (2003). Whale-watching tourists in West Scotland. Journal of Ecotourism, 2(2), 93-113.

Pope, J., Wessels, J.-A., Douglas, A., Hughes, M., \& Morrison-Saunders, A. (2019). The potential contribution of environmental impact assessment (EIA) to responsible 
tourism: The case of the Kruger National Park. Tourism Management Perspectives, $32,100557$.

Price, V., Tewksbury, D., \& Powers, E. (1997). Switching trains of thought: The impact of news frames on readers' cognitive responses. Communication Research, 24(5), 481506.

Roblek, V., Thorpe, O., Bach, M. P., Jerman, A., \& Meško, M. (2020). The Fourth Industrial Revolution and the Sustainability Practices: A Comparative Automated Content Analysis Approach of Theory and Practice. Sustainability, 12(20), 8497.

Rodrigues, H., Brochado, A., Troilo, M., \& Mohsin, A. (2017). Mirror, mirror on the wall, who's the fairest of them all? A critical content analysis on medical tourism. Tourism Management Perspectives, 24, 16-25.

Saarinen, J. (2014). Critical sustainability: Setting the limits to growth and responsibility in tourism. Sustainability, 6(1), 1-17.

Semetko, H. A., \& Valkenburg, P. M. (2000). Framing European politics: A content analysis of press and television news. Journal of Communication, 50(2), 93-109.

Sica, E., Sisto, R., Bianchi, P., \& Cappelletti, G. (2021). Inclusivity and responsible tourism: Designing a trademark for a national park area. Sustainability, 13(1), 13.

Sin, H. L. (2010). Who are we responsible to? Locals' tales of volunteer tourism. Geoforum, 41(6), 983-992.

Sin, H. L., \& Minca, C. (2014). Touring responsibility: The trouble with 'going local'in community-based tourism in Thailand. Geoforum, 51, 96-106.

Sirakaya, E., \& Sonmez, S. (2000). Gender images in state tourism brochures: An overlooked area in socially responsible tourism marketing. Journal of Travel Research, 38(4), 353-362.

Skal-International. (2020). Skal International presents the 2020 Sustainable Tourism Awards during its Annual General Assembly. $P R$ Newswire. Retrieved from https://www.prnewswire.com/news-releases/skal-international-presents-the-2020sustainable-tourism-awards-during-its-annual-general-assembly-301154367.html.

Smith, A. E., \& Humphreys, M. S. (2006). Evaluation of unsupervised semantic mapping of natural language with Leximancer concept mapping. Behavior research methods, $38(2), 262-279$.

Smith, V. L. (1990). Responsible tourismsome anthropological issues. Tourism Recreation Research, 15(1), 45-49.

Smith, V. L., \& Font, X. (2014). Volunteer tourism, greenwashing and understanding responsible marketing using market signalling theory. Journal of Sustainable Tourism, 22(6), 942-963.

Sotiriadou, P., Brouwers, J., \& Le, T.-A. (2014). Choosing a qualitative data analysis tool: A comparison of NVivo and Leximancer. Annals of Leisure Research, 17(2), 218-234.

Spenceley, A., Relly, P., Keyser, H.,Warmeant, P.,McKenzie, M., Mataboge, A., Norton, P., Mahlangu, S. and Seif, J. (2002). Responsible tourism manual for South Africa. Department for Environmental Affairs and Tourism. Retrieved from 
https://www.tourism.gov.za/CurrentProjects/ResponsibleTourism/Responsible\%20To urism/Responsible\%20Tourism\%20Manual.pdf.

Stepchenkova, S., \& Morrison, A. M. (2006). The destination image of Russia: From the online induced perspective. Tourism Management, 27(5), 943-956.

Szczepanski, M. (1992). Socially responsible travel. Beginnings (American Holistic Nurses' Association), 12(7), 6-6.

Sziakov. (2018). Iceland encourages responsible tourism with Pledge Button. eTurbo News. Retrieved from https://eturbonews.com/227754/iceland-encourages-responsibletourism-with-pledge-button/.

Tay, K. X., Chan, J. K. L., Vogt, C. A., \& Mohamed, B. (2016). Comprehending the responsible tourism practices through principles of sustainability: A case of Kinabalu Park. Tourism Management Perspectives, 18, 34-41.

UNESCO. (2020). Experts call for inclusive and regenerative tourism to build back stronger post-COVID-19. UNESCO World Heritage Centre. Retrieved from https://whc.unesco.org/en/news/2177.

United-Nations. (2017). The sustainable development goals report. Retrieved from https://unstats.un.org/sdgs/report/2017/

von der Weppen, J., \& Cochrane. (2012). Social enterprises in tourism: An exploratory study of operational models and success factors. Journal of Sustainable Tourism, 20(3), 497-511.

Wafik, G. M., Fawzy, N. M., \& Ibrahim, O. (2011). Official awareness of tourism carrying capacity dimensions in the fayoum destination's natural heritage sites (case of the valley of whales). International Journal of Hospitality \& Tourism Systems, 4(1).

Wan, C. (2019). The wrap: TAT, Expedia launch global sustainable tourism initiative in collaboration with UNESCO. Retrieved from https://www.webintravel.com/the-wraptat-expedia-launch-global-sustainable-tourism-initiative-in-collaboration-withunesco/.

Wang, G., Chang, W.-H., Cui, Y., Qi, G., \& Li, K. X. (2020). Introducing an economic impact platform to navigate cruise value-added chain with environmental considerations. Marine Policy, 112, 103713.

Wang, J., Liao, J., Wang, H., Zhu, X., Li, L., Lu, W., Song, G., \& Shen, Q. (2021). Quantitative and comparative study of plasmalogen molecular species in six edible shellfishes by hydrophilic interaction chromatography mass spectrometry. Food Chemistry, 334, 127558.

Wang, J., Liu-Lastres, B., Shi, Y., \& Li, T. (2019). Thirty years of research on tourism safety and security: A comparative automated content analysis approach. Journal of China Tourism Research,, 15(3), 340-358.

Wang, X., Yuen, K. F., Wong, Y. D., \& Li, K. X. (2020). How can the maritime industry meet Sustainable Development Goals? An analysis of sustainability reports from the social entrepreneurship perspective. Transportation Research Part D: Transport and Environment, 78, 102173. doi:10.1016/j.trd.2019.11.002

Weston, L., \& Bondy, J. (2010). Benidorm holds the key to sustainable tourism says new report.

Retrieved

from 
https://pressreleases.responsesource.com/news/61455/benidorm-holds-the-key-tosustainable-tourism-says-new-report/.

Wheeller, B. (1990). Responsible tourism. Tourism Management, 11(3), 262-263.

Wheeller, B. (1991). Tourism's troubled times: Responsible tourism is not the answer. Tourism Management, 12(2), 91-96.

Wheeller, B. (1994). Ecotourism: a ruse by any other name. Progress in tourism, recreation and hospitality management, 6, 3-11.

Wu, M.-Y., Wall, G., \& Pearce, P. L. (2014). Shopping experiences: international tourists in Beijing's silk market. Tourism Management, 41, 96-106.

Zaharia, N., \& Kaburakis, A. (2016). Bridging the gap: US sport managers on barriers to industry-academia research collaboration. Journal of Sport Management, 30(3), 248264.

Zimmerman, C., Bisanz, G. L., Bisanz, J., Klein, J. S., \& Klein, P. (2001). Science at the supermarket: A comparison of what appears in the popular press, experts' advice to readers, and what students want to know. Public Understanding of Science, 10(1), 37 58.

\section{Appendices}

Appendix 1: Literature table of 102 research articles eligible for ACA

Appendix 2: Literature table of 122 research articles eligible for ACA

Hyperlink: https://drive.google.com/file/d/15cAWPPW65LyaXlqY-2tA-zWC3HZenVnd/view 